\title{
The Scope and Potentials of Fodder Trees and Shrubs in Agroforestry
}

\author{
Jamala, G. Y.*, Tarimbuka, I. L, D. Moris and Mahai, S. \\ Adamawa State College of Agriculture, Ganye, Nigeria
}

\begin{abstract}
Fodder shrubs and trees (browse) play a significant role both in farming systems, where they are protected as fallow species, and in livestock production. The importance of browse increases with increasing aridity and is generally most essential in the dry seasons, when most other feed resources depreciate in quality and quantity. Generally, trees occupy a significant niche in the farming systems and overall way of life in animal production. Fodder trees and shrubs in Nigerian rangelands are classified into two groups: leguminous and non-leguminous. The leguminous trees and shrubs are often higher in crude protein and other nutrients and play a vital role as dietary supplements of low quality grasses in dry seasons. Livestock depend largely on browse for their dietary protein. Browse intake increases total dry matter intake, increases crude protein intake, and improves the digestibility of low-quality forages. The effect of browse feeding on livestock is shown in increased survivability (i.e., lower mortalities, especially over the dry season) and increased productivity. The processing and conservation of fodder trees and shrubs is increasingly being recognized and explored, while the cultivation is minimal and insignificant. The role and importance of fodder trees and shrubs for livestock production, their nutritional quality and factors which limit their use in livestock production are reviewed. The need for increased cultivation and integration of fodder trees (especially leguminous fodder trees and shrubs) into local farming systems through agroforestry is imperative in order to promote livestock production and also the support of rural livelihoods. It is also important to increased research support for the efficient cultivation, management, processing and use of fodder shrubs and trees for improved livestock production in Nigeria.
\end{abstract}

Keywords: Agroforestry, Livestock, Fodder trees, Leguminous, Farming system

\section{Introduction}

Fodder (browse) is an agricultural term for animal feed, and fodder trees and shrubs are those plants (shoots or sprouts, especially tender twigs and stems of woody plants with their leaves, flowers, fruits or pods) that are raised, used and managed to feed livestock. Fodder plants are plants which are grown in order to provide the nutritional needs of animals. Babayemi and Bamikole, (2006) opined that fodder and shrubs are important components of ruminant diet and they have been found to play an important roles in the nutrition of grazing animals in areas where few or no alternatives are available (Van et al., 2005). In a study conducted by Osemeobo (1996) it was observed that fodder is consumed in the livestock industry and the savannah areas account for about $10-15 \%$ fodder as livestock food in the dry seasons. These parts of the country have less rainfall and low biomass production but support over $90 \%$ of livestock. Fodder trees and shrubs were noted to support livestock such as-cattle, sheep, goats, donkey and camel - in the dry season.

NAERLS (2005) conducted a survey of trees and shrubs in the savannah zones, and found out that most trees and shrubs shed their leaves, the annual grasses die-off and the perennial grasses dry up and the vegetation is burnt thereby leaving the animals with little or nothing to eat. However, the plant parts such as new flush of leaves, flowers and fruits often produced in the dry season are rich in proteins, vitamins and minerals.

Ogunbosoye and Babayemi (2010) maintained that inadequate feed supply is a major constraint to ruminant production during the dry season in the tropics and this has been the basic reason for poor performance of livestock. Nevertheless, livestock rearing is considered as an occupation and source of income for the majority of resource-poor farmers in Africa. Sustainable production of livestock usually involves efficient utilisation of available feed resources. However, the low quality and quantity of available forages during the dry season are major constraints for improved livestock production in most savannah areas. In many rural areas, the available grazing is not generally sufficient to meet the maintenance requirements of grazing animals (Matlebyane et al., 2010) during dry periods.

As a major source of animal feeds in Africa, fodder trees and shrubs are highly valued by farmers. Browses have multiple roles in farming systems such as feed, fuel wood and as human and veterinary medicines (Luseba and Van der Merwe 2006). These forage species contain appreciable amounts of nutrients that are deficient in other feed resources such as grasses during dry seasons and dry periods. They have deep root systems enabling the extraction of water and nutrients from deep in the soil profile (Teferi et al., 2008). Most browse plants have high crude protein content, ranging from 10 to more than $25 \%$ on a dry matter basis 
(Moleele, 1998). This reliable protein resource can be used to develop a sustainable feeding system and increase livestock productivity.

Livestock play a very important role in Nigerian agriculture contributing about $12.7 \%$ of the total agricultural GDP (CBN, 2009). Nigeria is one of the four leading livestock producers in Sub-Sahara. Livestock population comprised about 15.2 million cattle, 28 million goats and 23 million sheep (FAO, 2006). In Nigeria ruminant livestock are numerous and provide substantial quantities of animal protein. However, their production is based on age-old husbandry systems, which need to be gradually modified in order to meet the needs of consumers. In Nigeria, cattle, goats and sheep production systems are predominantly traditional or village systems; nomadic or pastoral systems; mixed farming and the peri-urban and modern ruminant livestock husbandry. In general production and management systems vary from free range in less populated areas to year round confinement and cut and carry feeding of grass and browse in densely populated areas (FAO, 2009). Trees and shrubs are particularly important in pastoral production systems. Communities who gain their livelihood from herding animals depend for their survival on an intimate knowledge of their environment. Trees and shrubs are recognised as an essential component within these systems.

\section{Scope and applications of fodder trees and shrubs}

Elevitch and Wilkinson (2000) pointed out that fodder trees and shrubs have several applications and uses and hence they serve as good sources of Shade, Wind shelter, Living fence, Improved fallow, Improved pasture, Mulch, Bee forage, Human food, Fuel wood, Timber, Fiber, Resins, Dyes, Tannins, Medicine, Food, Fertility enhancement, Soil stabilization, Beauty, Oxygen, Wildlife habitat, Bird habitat, Increased selfsufficiency, Nutrient cycling, Farm diversity.

In a previous study conducted by Komwihangilo et al. (2001) farmers reported that most browsed species were observed according to their voluntary intake and subsequent performance of browsers on different fodder trees and shrubs. For example, Dichrostachys cinerea was reported as the most preferred species by both cattle and goats in South African regions. Local people generally recognise the trees and shrubs which are well appreciated by ruminants and their nutritive importance.

According to Aganga and Tshwenyane (2003) the parts of trees that are commonly used as feed include leaves, tender shoots or twigs, fruits, pods and seeds. In general, leaves are higher in crude protein (almost twice) than twigs, indicating that livestock have access to nutritious feed. Leaves also contain more crude protein on average than pods but the latter were found with higher organic matter and digestibility.

\section{Major fodder shrub and tree species}

Several authors have described tree species used to supply animal feeds to different categories of livestock. Emmanuel and Tsado (2011) noted that in all fodder development works, legumes play the major role as they enrich the soil with nitrogen and produce highly digestible and protein rich fodder. The family of legume is one of the biggest in the plant kingdom. Almost all plants are used as fodder belongs to the sub- family papilionoidese.

Table 1: Some Important Fodder trees and shrubs in Nigeria

\begin{tabular}{|c|c|}
\hline Scientific names & Habitat \\
\hline Acacia albida & Savannah \\
\hline Acacia niotica & $"$ \\
\hline Acacia raddiana & $"$ \\
\hline Acacia senegal & $"$ \\
\hline Acacia tortilis & $"$ \\
\hline Adansonia digitata & $"$ \\
\hline Afzelia Africana & $"$ \\
\hline Albizia Zysia & Forest/Savannah \\
\hline Albizia lebbeck & \\
\hline Anogeissus leiocarpus & Savannah \\
\hline Anona Senegalensis & " \\
\hline Balanites aegyptiaca & $"$ \\
\hline Borassus eathiopium & $"$ \\
\hline Bridelia spp. & $"$ \\
\hline Ceiba pentandra & Forest/Savannah \\
\hline Danellia oliveri & Savannah \\
\hline Detarium Microcarpum & $"$ \\
\hline Ficus capensis & $"$ \\
\hline Ficus polita & Savannah \\
\hline Isoberlina doka & $"$ \\
\hline Khaya senegalensis & $"$ \\
\hline Leucaena leucocephala & Forest/Savannah \\
\hline Nauclea latifolia & Savannah \\
\hline Gardenia terifolia & $"$ \\
\hline
\end{tabular}


The Scope And Potentials Of Fodder Trees And Shrubs In Agroforestry

\begin{tabular}{ll}
\hline Gliricidia sepium & Forest/Savannah \\
Parkia biglobosa & $"$ \\
Prosopis Africana & $"$ \\
Prosopis julifera & Savannah \\
Strychnos innocua & $"$ \\
Tamarindus indica & \\
\hline
\end{tabular}

Adopted from: Osemeobo (2006)

\section{Nutritional value of some fodder trees and shrubs}

Leguminous species were found to contain 25 to $50 \%$ more crude protein than non-leguminous plants. Mokoboki et al. (2005) reported the nutritional values, the type and amount of tannins of acacia tree foliage (Acacia karroo, Acacia nilotica, Acacia tortilis, Acacia galpinii, Acacia sieberiana, Acacia hebeclada and Acacia rhemniana). Almost all species had crude protein levels above $100 \mathrm{~g} / \mathrm{kg}$ dry matter (DM), ranging from $103 \mathrm{~g} / \mathrm{kg} \mathrm{DM}$ for A. rhemniana to $183 \mathrm{~g} / \mathrm{kg}$ DM for A. sieberiana. Crude protein (CP) levels of this magnitude in a diet are adequate to support the requirements of cattle, sheep and goats at low to medium production levels. Mokoboki et al. (2005) concluded that all the species except A. galpinii, A. karoo and A. tortillis are of good nutritive value. Dichrostachys cinerea is a valuable fodder tree and there are various beneficial effects resulting from supplementing ruminants with $D$. cinerea. Smith et al. (2005) reported improved performance of goats resulting from supplementation with $D$. cinerea fruits. Basha et al. (2009) reported $D$. cinerea to have 123.2 $\mathrm{g} / \mathrm{kg} \mathrm{CP}$, and low tannin content $(57.9 \mathrm{~g} / \mathrm{kg})$.

The chemical composition of combretum species (C. apiculatum, C. molle and C.zeyheri) was well determined by Lukhele and Van Ryssen (2003). Mean values CP concentration varied from $92 \mathrm{~g} / \mathrm{kg}$ DM for $C$. molle to $141 \mathrm{mg} / \mathrm{kg}$ DM for C. mopani. These values are comparable to those reported for acacia species (Mokoboki et al., 2005). Ficus sycomorus is also among the identified browse species since it provides fruits and leaves. Nutritional status of this species was determined by Nkafamiya et al. (2010). Results obtained for proximate composition showed protein content of $17.24 \pm 0,71 \%$ and it has a high percentage of crude fibre $(31.54 \pm 0,11 \%)$. They concluded that F.sycomorus can serve as a good source of nutrients. Diospyros mesipiiformis was found to have low levels of CP $(5.46 \mathrm{~g} / \mathrm{kg})$ but high levels of total carbohydrates $(77.21 \%)$ (Ezeagu, et al., 2002).

\section{Veterinary uses of some local fodder trees and shrubs}

From a study on ethnoveterinary medicine conducted on some local fodder trees and shrubs, it is revealed that many of these plants have both nutritional and therapeutic properties (Kharb and Singh 2004). For example, Dombeya rotundifolia was evaluated for its biological activity. It showed antibacterial and anthelmintics activities (MacGaw et al., 2007). Aqueous and organic leaf extracts of $C$. hereroense showed good activity in in vitro assays against the free-living nematode Caenorhabditis elegans (MacGaw et al., 2001). Members of combretacea have been extensively studied and shown to have broad-spectrum antimicrobial activity (Martini et al., 2001; Katerere et al., 2003; Eloff et al., 2008). Several flavonoids, trriterpenoids, and stilbenoids have been isolated from Combretaceae and were shown to be biologically active (Alves et al., 2010).

Maphosa et al. (2010) reported that species from Fabaceae family are used to treat various animal diseases, ranging from bacterial diseases to conditions caused by internal and external parasites. Peltophorum africanum was reported by Bizimenyera et al. (2005) to have anthelmintic and antioxidant activities.

\section{Pattern of utilization of fodder trees and shrub species}

Fodder is harvested in the natural environments through: (i) selective cutting of leafy parts, flowers and fruits of shrubs and trees. (ii) Pruning of shrubs and trees which are suitable for livestock. (iii) Pollarding of tree crowns (Osemeobo 2006).

In a recent survey conducted by Hassen et al. (2010) they observed that parts of the browse species utilized by livestock were leaves, pods, twigs and flowers. In all browses, leaves were the plant parts mostly utilized by livestock. The pods of Acacia tortilis and Dichrostachys cinerea were important feed resources for goats during the dry season. Dried leaves were found to be more palatable for cattle and goats than wet leaves from broad leaved browse species like Terminalia brownii, Boswellia papyrifera and Sterculia africana.

Also in a study conducted by Javed, et al. (2008) they found out that fodder tree leaves are an alternative source of livestock feeding in scarcity period, especially in prolonged dry season. The fodder tree leaves are harvested several times during summer and fed to livestock and also stored as hay. They maintained that rangeland grasses are although the main way of procuring feed, yet fodder trees plays an important role in livestock rising. 


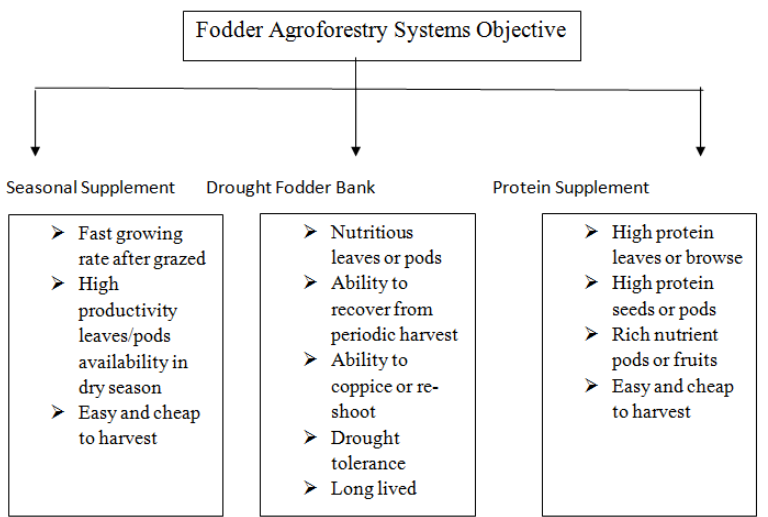

Figure 1: Characteristics of Fodder trees and shrubs in Agroforestry System Objectives, Adopted from Abel et al. (1997)

\section{Common Agroforestry-Fodder Production Models}

According to Calub and Lasco (1999) a number of fodder production systems designed to produce sufficient foliage for livestock feeding particularly during the dry season were evaluated and a lot of research is still being conducted with several others being refined. These production systems include various types of agroforestry-silvopastoral systems, where trees, animals and pastures are deliberately combined to obtain benefits and services. The integration of these components can vary both in time and in space.

\section{Fodder bank systems}

Trees are planted as close as $1 \mathrm{~m} \times 1 \mathrm{~m}$ and are cut regularly to induce maximum herbage production. The cut herbage is usually carried to animal feeding stalls, sometimes sheep or goats are brought to the plots and allowed to forage on the cut branches of naturally-growing fodder. The system is called fodder bank, which provides reserve fodder when it is in short supply, usually in the dry season.

\section{Protein bank}

This is a type of fodder bank which intentionally chooses trees, shrubs legumes with high proteincontaining leaf biomass. Commonly used species include Leucaena leucocephala, Gliricidia sepium,

\section{Three-strata forage system}

This is another type of fodder bank; it involves the planting of forages, shrubs and trees to form three canopy layers or strata in a unit of land. Pasture grasses, vines and herbs occupy the lower strata; shrubs occupy the middle strata and trees occupy the upper strata. The combination of grasses and trees can ensure year-round supply of fodder.

\section{Live fence or boundary systems}

Single or double rows of fodder trees are planted along farm boundaries. The trees have the dual purpose of providing fodder and serving as live fence posts. If intended to enclose animals, the trees are usually planted densely, as in hedges, to prevent animals from getting out. In some parts of Africa, thorny species are planted as thick hedges to prevent livestock from straying into crop plots and also to fence them off from wild animals.

\section{Hedgerow intercropping systems}

Fodder trees, mostly leguminous are planted as hedges in single, double or triple rows. The spaces in between hedgerows are planted with pasture grasses. As in fodder banks, herbage may be cut and carried to animal feeding stalls. The more common practice is to let the animals forage on the cut tree branches and pasture grasses.

\section{Tree plantation + animal grazing systems}

The understory of tree plantations is utilized as grazing area for cattle, sheep and goats. The plantation may be of forest trees, fruit trees, coconuts, oil palms or rubber. The livestock are allowed to graze freely on improved pasture grasses planted under trees. 


\section{Indigenous cut-and-carry systems}

As the name implies, the fodder is cut and carried to animal stalls. Farmers have long been practicing this system. Indigenous legumes such as Ficus, Acacia, Leucaena, Gliricidia and Albizia are the most preferred fodder tree species.

\section{Contributions of Fodder trees and Shrubs to food Security}

Fodder trees and shrubs form an integral part of ruminant production; feeding browse has become an essential practice especially in the dry season when herbaceous forages are scarce (Bamikole et al., 2004) and low in nutritive value (Aregheore, 2001). Forage legumes, especially browse plants, are important in the maintenance and survival of ruminants. Their relative importance in ruminant nutrition especially during the dry season spell cannot be over-emphasized. Improved animal agroforestry could enhance livestock production in Nigeria through forage production. As a fraction of total fodder intake during the dry season, browse can contribute as much as $30 \%$ of cattle's and $60 \%$ of goats' fodder. Large number of browse legumes and multipurpose trees have been tried experimentally and subsequently introduced to ruminant farmers.

Fodder legumes are of considerable nutritional importance as livestock feed during the dry season of the year. Their leaves are green all year round and many are well known to herdsmen who frequently cut down their branches for stock feeding. Most nomads and smallholders know them and therefore use them for their livestock (Aregheore, 1996; Onwuka et al., 1992). The fruits of some form an important feed resource during the dry season. Many browses contain high levels of essential elements such as calcium, sodium and sulphur as well as critical micronutrients such as iron and zinc which have been shown to be deficient or borderline for productive purposes in many grass species.

Browse legumes are found from north to south; and west to east in Nigeria. Examples include Leucaena leucocephala, Gliricidia sepium, Acacia spp. (A. albida, A. nilotica), Albizia, Ficus elasticoides, Mangifera indica, Musa sp., Spondias mombin, Cajanus cajan, Tamarindus indica, and Parkia clappertonian. Leucaena is widely accepted as the best browse legume and has naturalized in some parts of Nigeria. Leucaena and Gliricidia foliage yields are higher in the wet season (Aregheore, 1995; Balogun and Otchere, 1995). Their leaves provide protein-rich supplements to traditional village diets to increase small ruminant productivity.

Bamikole et al., (2003) evaluated the feeding value of Ficus religiosa with West African Dwarf goats and the results demonstrated that feed intake, weight gain, digestibility and $\mathrm{N}$ utilization can be enhanced by feeding Ficus religiosa in mixture with Panicum maximum and it can be used in diet mixtures up to $75 \%$ of DM fed. Yahaya et al. (2001) evaluated the nutritive value of three browse trees (Ficus polita, F. sycomorus and Acacia sieberiana) with sheep on dry matter and crude protein digestibility; and degradability of neutral detergent fibre and Acid detergent fibre. Results of the investigation demonstrated that Acacia sieberiana, F. polita and $F$. sycomorus can sustain sheep on a maintenance diet and could also be used as a supplementary feed during the dry season. Silvopastoral systems that incorporate native trees and shrubs are instrumental for the productive rehabilitation of cattle production and for biodiversity conservation in agricultural landscapes. Silvopastoral systems are a sustainable form of agroforestry for livestock production that combines fodder shrubs.

\section{Conclusions and Recommendations}

Several studies revealed that fodder trees and shrubs play significant roles within the farming system. The potential of leguminous fodder trees can be seen in their multipurpose nature and their ease of integration into existing farming systems. Leguminous fodder trees can be used for the improvement of both crop and livestock production and thus offer a means of linking livestock production with arable crop production. They are therefore immensely suitable for the improvement of farming systems through soil fertility maintenance (for crop production) and increased availability of high-protein feed for livestock. Generally, the inclusion of leguminous trees in tropical land-use systems offers many advantages at minimum expense. The potentials of fodder trees and shrubs remain vital in the support of rural livelihoods and food security.

Since most works carried out on fodder production are successful in the humid and sub humid regions, fodder trees production should be concentrated in these areas and fodder should be preserved and transported to the major livestock zones in the semi-arid and arid areas. Simple conservation and preservation techniques are required for the operation of such a system and to ensure that quality of forage is maintained.

The protection of trees, particularly browse trees, remains a major problem, especially in the dry areas. Governments should educate the local people on the dangers, both to livestock and to the environment, of overexploitation, and initiate the organization of community-based efforts to improve and properly manage grazing reserves and rangelands.

There is also a need for collaborative efforts between the scientists and farmers. Bigglelaar, (1995) maintained that most of the work do not have to be done by researchers alone. Many farmers have indigenous knowledge of effective Tree + Livestock + Pasture schemes, which when combined with scientific research can 
increase the current knowledge on agroforestry systems and also the general acceptability of the system by the farmers.

\section{Future Research}

A lot of work remains to be done in the area of trees and shrubs as browse species. One of the first requirements is a comprehensive list of browse species and their foliar physiology should receive more attention. It could be useful also to select lines of trees which keep their leaves longer than usual on the stem. More should be known on the management of browse species. This would make it possible to avoid the disappearance of some species by over-utilisation, as occurs with Terminalia avicennioides in the region of Maradi (Niger).

\section{References}

[1]. Aganga A A and Tswenyane S O (2003). Feeding value and anti-nutritive factors of forage tree legumes. Pakistan Journal of Nutrition 2: 170-177.

[2]. Alves R R N, Barboza R R D and Souto W M S (2010). Plants used animal health care in South and Latin America. In: Katerere D. \& Luseba D. (Eds). Ethnoveterinary Botanical Medicine: Herbal Medicine for Animal Health, Life Science Division, CRC Press, Boca Raton, USA.

[3]. Aregheore, E.M. and Yahaya, M.S. (2001). Nutritive value of some browses as supplement for goats. Malaysian Journal of Animal Science, 7(1):29-36.

[4]. Aregheore, E.M. (1996). Natural grassland and ruminant interactions in the dry season in Delta State, Nigeria. World Review of animal Production. 31(1-2):74-79.

[5]. Babayemi, O.J., Bamikole, M.A. (2006). Supplementary value of Tephrosia bracteolate, Leucaena leucocephala, and Gliricidia sepium hay for West African Dwarf goats kept onRange. Journal Central European Agriculture, 7(2): 323-328

[6]. Balogun, R.O. and Otchere, E.O. (1995). Effect of Leucaena leucocephala in the diet on feed intake, growth and feed efficiency of Yankasa rams. Tropical Grasslands, 29:150-154.

[7]. Bamikole, M.A., Ikhatua, U.J., Arigbede, O.M., Babayemi, O.J. and Etela, I. (2004). An evalauation of the acceptability as forage of some nutritive and antinutritive components and of the dry matter degradation profiles of five species of Ficus. Tropical Animal Health and Production, 36:157-167.

[8]. Bamikole, M.A., Babayemi, O.J. Arigbede, O.M. and Ikhatua, U.J. (2003). Nutritive value of Ficus religiosa in West African dwarf goats. Animal Feed Science and Technology, 105 (1-4):71- 79.

[9]. Biggelaar DC. (1996). Farmer experimentation and innovation. A case study of knowledge generation process in Agroforestry systems in Rwanda. Community Forestry Case Study Series No. 12. FAO. Rome

[10]. Bizimenyera S E, Swan G E, Chikoto H and Eloff J N (2005). Rationale for using Peltophorum africanum (Fabaceae) extracts in veterinary medicine. Journal of South African Veterinary Association 76: 54-58.

[11]. Calub BM and RD Lasco. (1999). Indigenous trees and shrubs as fodder in the drought-prone areas of Batangas. Proceedings of the $36^{\text {th }}$ Annual Convention of the Philippine Society of Animal Science. Manila, Philippines; SAS.

[12]. CBN (Central Bank of Nigeria). (1999). Annual report 1999. CBN, Lagos, Nigeria.

[13]. Chepape R M, Mbatha K R and Luseba D (2011). Local use and knowledge validation of fodder trees and shrubs browsed by livestock in Bushbuckridge area, South Africa. Livestock Research for Rural Development. Volume 23, No. 132. Retrieved August 31, 2012, from http://www.lrrd.org/lrrd23/6/chep23132.htm

[14]. D. O. Ogunbosoye and O. J. Babayemi (2010). Potential values of some non-leguminous browse plants as dry season feed for ruminants in Nigeria. African Journal of Biotechnology Vol. 9 (18), pp. 2720-2726, 3 May, 2010 Available online at http://www.academicjournals.org/AJB ISSN 1684-5315

[15]. Elevitch, C.R. and K.M. Wilkinson. (2000). Agroforestry Guides for Pacific Islands. Permanent Agriculture Resources, P.O. Box 428, Holualoa, HI 96725.

[16]. Eloff J N, Katerere D R and McGaw L J (2008). The biological activity and chemistry of the southern African Combreteceae. Journal of Ethnopharmacy 119 (3): 686.

[17]. Emmanuel L S. and D. N Tsado (2011). Forage and Fodder Crop Production in Nigeria: Problems and Prospects. World J Life Sci. and Medical Research 2011;1(4):88

[18]. Ezeagu I E, Metges C C, Proll J, Petzke K J, and Akinsoyi-znu A O (1996). Chemical composition and nutritive value of some wild-gathered tropical plant seeds. Food and Nutrition Bulletin 17 (3): 104

[19]. FAO (2009). Country Pasture/Forage Resource Profiles Nigeria, Research and Extension, FAO, Viale delle Terme di Caracalla, 00153 Rome, Italy

[20]. FAO (1993). Agriculture: Towards 2010 Food and Agriculture Organization of the United Nations, Rome, Italy.

[21]. FAO (2001). Bulletin of Statistics, Vol. 2 (2). Rome, Italy.

[22]. Hassen A, Ebro A, Kurtu M and Treydte A C (2010). Livestock feed resources utilization and management as influenced by altitude in the Central Highlands of Ethiopia. Livestock Research for Rural Development. Volume 22, No. 229. Retrieved September 10, 2012, from http://www.lrrd.org/lrrd22/12/hass22229.htm

[23]. http://www.fao.org/docrep/003/T0632E/T0632E04.htm (access on 28/09/2012)

[24]. http://www.agricultureguide.org/fodder-plants-all-everything-you-want-to-need-know-a- featured-article/(accessedon 28/09/2012)

[25]. Javed Iqbal Sultan, Inam-Ur-Rahim, Haq Nawaz, Muhammad Yaqoob And Ijaz Javed (2008). Nutritional evaluation of fodder tree leaves of Northern grasslands of Pakistan. Pak. J. Bot., 40(6): 2503-2512, 2008.

[26]. Katerere D R, Gray A I, Nash R J and Waigh R D (2003). Antimicrobial activity of pentacyclic triterpenes isolated from Africa Combretaceae. Phytochemistry 63: 81-88.

[27]. Kharb S and Singh V (2004). Nutriceauticals in health and disease prevention. Indian Journal of Clinical Biochemistry, 19(1): 5053.

[28]. Komwihangilo D M, Sendalo D S C, Lekule F P, Mtenga L A and Temu V K (2001). Farmers'knowledge in the utilization of indigenous browse species for feeding of goats in semi arid central Tanzania. Livestock Research for Rural Development 13(6).

[29]. Lukhele M S and Van Ryssen J B J (2003). The chemical composition and potential nutritive value of the foliage of four subtropical tree species in Southern Africa for ruminants. South African Journal of Animal Science 33 (2): 132-141. 
[30]. Luseba D, Tshikudo M L, Chepape R M and Tshisikhawe P (2011). Medicinal plant used in the treatment of livestock disease in Vhembe region, Limpopo province, South Africa. Ethnobotany Research and Applications

[31]. Luseba D and Van der Merwe D (2006). Ethnoveterinary medicine practices among Tsonga speaking people of South Africa. Onderstepoort Journal of Veterinary Research 73: 115- 122.

[32]. Maphosa V, Tshisikhawe P, Thembo K and Masika P (2010). Ethnoveterinary medicine in Southern Africa. In: Katerere D. \& Luseba D. (Eds). Ethnoveterinary Botanical Medicine: Herbal Medicine for Animal Health, Life Science Division, CRC Press, Boca Raton, USA.

[33]. Martin N D, Katerere D R and Eloff J N (2001). Biological activity of five antibacterial flavonoids fromCombretum erythrophyllum (Combretaceae). Journal of Ethnopharmacology 92: 207-212.

[34]. Matlebyane M M, Ng'ambi J W W and Aregheore E M (2010). Indigenous knowledge (IK) ranking of available browse and grass species and some shrubs used in medicinal and ethno-veterinary practices in ruminant livestock production in Limpopo province, South $\quad$ Africa. Livestock Research for Rural Development 22(3).

[35]. McGaw L J, Rabe T, Sparg S G, Jager A K, Eloff J N and Van Staden J (2001). An investigation on the biological activity of combretum species. Journal of Ethnopharmacology 75(1): 45-

$\mathrm{J}(2001)$. An investigation on the biological activity of
50 . McGaw L J, Van der Merwe D and Eloff J N (2007). In vitro anthelmintic, antibacterial and
plants used in South African ethnoveterinary medicine. The Veterinary Journal 173: 366-372.

[37]. Mokoboki H K, Ndlovu L R, Ng'ambi, J.W, Malatje, M M and Nikolova R V (2005). Nutritive value ofAcacia tree foliage growing in the Limpopo Province of SA. South African Journal of Animal Science, 35: 221-228.

[38]. Moleele NM (1998). Encroacher woody plant browse as feed for cattle. Cattle diet composition for three seasons at Olifants Drift, south-east Botswana. Journal of Arid Environments $\quad$ 40: 255-268.

[39]. NAERLS (2005). Trees and Shrubs species for fodder in Nigeria. Extension Bulletin 57(3):1-27

[40]. Onwuka, C.F.I., B.B.A. Taiwo and Adu, I.F. (1992). Browse species and supplements utilized for small ruminant feeding in Ogun state of Nigeria. In: Stares, J.E.S, Said, A.N. and Kategile, J.A. (ed). The complementarity of feed resources for animal production in Africa. Proceedings of the Joint Feed Resources Networks Workshop held in Gaborone, Botswana, 4-8 March 1991. Africa Feeds Research Network. ILCA (International livestock Centre for Africa). Addis Ababa, Ethiopia. Pp 173-180.

[41]. Osemeobo, G..J. (2006). Natural Resources Management and in situ Plant Genetic Conservation in Nigerian Arid Zones International Plant Genetic Resources Institute Kenya, 144pp

[42]. Smith T, Mlambo V, Sikosana J L N, Maphosa V, Mueller-Harvey I and Owen E (2005). Dichrostachys cinerea and Acacia nilotica fruits as dry season feed supplements for goats in a semi-arid environment. Animal Feed Science and Technology 122: 149157. http://www.sciencedirect.com/science?

[43]. Terefi A, Solomon M and Lisanework N (2008). Management and utilization of browse species as livestock feed in semi-arid district of North Ethiopia. Livestock Research for Rural Development, 20.

[44]. Yahaya, M.S., Kibon, A., Aregheore, E.M., Abdulrazak, S.A., Takahashi, J and Matsuoka, S. (2001). The evaluation of nutritive value of three tropical browse species for sheep using in vitro and in vivo digestibility. Asian-Australasia Journal of Animal Science, 1494):496- 500.

[45]. Van, D.T.T., Mui, N.T., Ledin, I. (2005). Tropical foliages: effect of presentation method and species on intake by goats. Animal Feed Science and Technology, 118: 1-17. 